\title{
THE ORCHID RECOVERY PROGRAM AT ILLINOIS COLLEGE - A SUCCESSFUL BLEND OF TEACHING, RESEARCH AND UNDERGRADUATE STUDENT PARTICIPATION TO BENEFIT ORCHID CONSERVATION
}

\author{
LAWRENCE W. ZETTLER \\ Director, Orchid Recovery Program, Illinois College \\ 1101 West College Avenue, Jacksonville, Illinois 62650 USA \\ lwzettle@ic.edu
}

KeY WoRDs: orchid conservation, North America, undergraduate students, research, liberal arts

\begin{abstract}
A decade ago (1996), the Orchid Recovery Program was established at Illinois College - a private liberal arts college - to promote the conservation of rare orchids through propagation. The school's rural location, small size (1,000+ undergraduate students), and heavy teaching load ( $=12$ hours/semester) posed serious challenges to the establishment of this research program. Nevertheless, over the years several aspects of the College were identified, targeted, and integrated to successfully blend the student academic experience with orchid conservation. This paper provides a summary of the mechanisms that led to the establishment and success of the program, and describes how meaningful research is indeed possible at smaller colleges, not just at large research institutions.
\end{abstract}

Historically, large research institutions in the United States and elsewhere have instilled an attitude of "publish or perish" as a necessary means to achieve tenure and promotion in its faculty members. During the past 10-20 years, faculty members have also faced increasing pressure to secure sizable external grants to support research and, in some cases, salary. As a result, faculty members appear to be evolving into aggressive entrepreneurs, raising concerns that such a mindset has the potential to adversely affect science itself. This shift has also led to a kind of natural selection where "high tech" research is favored over basic organismal biology, probably because the former brings in more cash flow and prestige. Compounding matters, specialists trained in organismal biology are being steadily phased out usually via retirement - in favor of the entrepreneur. Those that remain at the larger institutions have been relegated to smaller working spaces (e.g., hallway closets), or become employed elsewhere. Some find shelter from administrators by teaching. Ironically, these organismal biologists are still in demand on some levels, including those that cut and grind specimens in search of high tech answers.

This environmental pressure has triggered an evolutionary process in academia and a significant transformation is now underway - young organismal biologists are seeking employment at smaller, teaching oriented, undergraduate institutions where the pressure to publish and secure external funds is (currently) significantly less. Nevertheless, administrators at smaller institutions now recognize the importance of undergraduate research, probably because of its potential to lure exceptional prospective students (= cash) away from competing institutions. This seems especially true of private colleges whose livelihood depends on student enrollment and retention. Consequently, the expectation for undergraduate research in this setting is on the rise, and faculty members are faced with the added burden of also maintaining high teaching standards.

The abovementioned scenario seems dire for faculty, students and science itself. When the ongoing global loss of biological diversity is also considered, the future is clearly troublesome. The next generation - today's students - will inherit a wildly changing planet and they will also serve as caretakers of the world's natural resources. To do the latter effectively, they must truly care about all creatures great and small, and they must understand and appreciate how each species interacts within the broader ecological framework. Unfortunately, the music of life itself has been masked or replaced by the sounds produced by 
our machines, and poisoned by the pollution that made these machines. Technological devices (e.g., cell phones, video games) have infiltrated society and are firmly embedded within the everyday lives of today's college student. Technology is inevitable and good, but only if used responsibly, and not at the expense of a quality education, or at the expense of the environment.

\section{The Foundation for Orchid Research at a Small College}

Founded in 1829, Illinois College was the first college or university in the state of Illinois to hold classes and award higher education degrees. Today, the College educates $c a$. 1,000 undergraduates in a curriculum rooted in the liberal arts. The Mission Statement of the College emphasizes the "development of mind and character needed for fulfilling lives of leadership and service". Similarly, the College's Statement of Community Responsibility emphasizes that "we are all caretakers of our community and recognize that our individual responsibilities are essential for nurturing collaborative relationships, critical exploration, and global awareness". Thus, the public doctrine of the College is structured, at least in theory, to support biological (orchid) conservation. The fusion of orchid research into the curriculum, therefore, can be viewed as one tool by which undergraduate students become liberally educated and ultimately, responsible caretakers. The Biology Department at Illinois College has catalyzed this process even further. Biology students (= science majors) are provided with introductory courses their freshman year (e.g., basic chemistry and biology), then have the opportunity to take specialized courses in several tracts of study (e.g., marine biology, botany, pre-medicine).

One such course in particular, Introduction to Research, has been instrumental in engaging undergraduates in research and the scientific method. As a regularly offered course, it is counted towards the faculty member's teaching load. Therefore, it serves to ease the burden of a high teaching load normally associated with smaller colleges. A prerequisite of the course are two vigorous core courses required of science majors their freshmen year, General Biology I and II. Students that then enroll in Introduction to Research are adequately prepared to conduct experiments because they have received fundamental bio- logical knowledge beforehand. Once enrolled, students learn about research by doing research.

According to student evaluations and interviews, a key ingredient in the success of the Introduction to Research course lies in the nature of the experiments, their outcomes, and their application to real-world problems. Students that design and conduct experiments aimed at improving orchid conservation are provided with a greater sense of responsibility and personal achievement. Students are often awestruck by the realization that they are actually engaged in a research project that has the potential to ultimately save an orchid species from extinction. For most, this serves as a "wake up call" that opens their minds and hearts to the plight of orchids and other organisms threatened worldwide. Many also realize the power of the scientific method, and realize that science is both challenging, but enjoyable.

\section{The Components of the Orchid Recovery Program at Illinois College.}

Upon completion of the Introduction to Research course, students interested in pursuing other, similar projects are encouraged to do so during their last two years of study. This was the catalyst for the formation of Illinois College's Orchid Recovery Program. The core of the Orchid Recovery Program lies in the undergraduates that fuel it. Students play an active role collecting information (literature searches), designing experiments, writing grants (internal and external to the College), gathering/analyzing data, contributing to manuscripts, and giving scientific presentations. For this to work effectively, the personality traits of each student must be identified so that his or her strengths can be realized. Thus, each student is viewed as a unique, pliable individual with a different set of strengths - not a clone of the supervisor. Matching the various strengths and personality traits within the lab group is challenging but possible considering that each student was previously evaluated via the teaching process (General Biology I, II and Introduction to Research). This is yet another way that teaching complements research. Because of the College's small size and (still) healthy endowment ( $>\$ 100$ million), a manageable number of students (e.g., 1-5) are engaged in the research program at any given time, and some receive pay via college-supported stipends.

Students with seniority and/or the most experience 
serve as leaders within the group, and are provided with personal desk space within the lab. As a result, student leaders serve as a conduit between the supervisor and the students with the least experience. This is a critical aspect of the program because the student leader's role makes it possible for the supervisor to concentrate more on teaching nine months of the year (September-May). The other three months (JuneAugust) are dedicated entirely to research. During this time, the supervisor works closely with each student to design/implement experiments, improve training, travel, and carry out field-based research (e.g., seedling reintroductions). Students also collaborate directly with leading specialists at other institutions during this time. Once this fundamental groundwork has been established, the supervisor is then free to concentrate on teaching once again. In short, students are trained over the summer, and collect data when classes are in session, often between classes. Data collected during the teaching months by students are then analyzed over the next summer, leading to manuscripts and presentations. Because students play an integral role in this process, they often (deservingly) serve as co-authors. The end result is a liberally educated, self-confident, responsible, and experienced graduate (= caretaker) that is marketable through the eyes of many graduate programs nationwide. Some students have opted to continue research aimed at orchid conservation (e.g., Kurt Piskin, PhD student, St. Louis University; Scott Stewart, PhD student, University of Florida), whereas others have chosen other fields (e.g., Chris Wagoner, medical student, University of Illinois). Regardless of their ultimate career choice, the Orchid Recovery Program has instilled in each student an appreciation for orchids and their conservation (see Stewart 2002, and Zettler 2006).

\section{Specific Examples of Student Research Projects VIA the Orchid Recovery Program}

During the past 10 years, a total of 36 undergraduate students have received training through the Orchid Recovery Program. Among the rare orchid taxa studied include two U.S. Federal listed Platanthera species, as well as several state-listed species in other genera (Table 1). Most of the research has investigated the role and use of mycorrhizal fungi to propagate terrestrial orchids from seed (= symbiotic seed germination). Several species have been successfully cultivated in this manner leading to seedling reintroduction in suitable habitats (e.g., Habenaria macroceratitis Willd., Spiranthes brevilabris Lindl.). Recently (2004-present), students have examined the feasibility of applying the symbiotic technique to epiphytic orchids using Epidendrum nocturnum Jacquin as a model. Such student-led work has the potential to change and improve the way epiphytic orchids are conserved worldwide. Ongoing and future work is also being carried out to improve seedling survival in Platanthera holochila (Hbd.) Krzl. - a U.S. Federal listed (global rank C1)

TABLE 1. Endangered, rare or otherwise uncommon orchids studied by undergraduate students via the Orchid Recovery Program at Illinois College during the past decade. All references listed were authored or co-authored by one or more undergraduate students.

\begin{tabular}{|c|c|c|}
\hline Orchid & Status & Reference(s) \\
\hline Epidendrum nocturnum (Jacq.) & Endangered in FL & Zettler et al. 2006 \\
\hline Habenaria macroceratitis Willd. & Endangered in FL & Stewart \& Zettler, 2002 \\
\hline Platanthera holochila (Hbd.) Krzl. & U.S. Federal Endangered & Zettler et al. 2005a \\
\hline P. integra (Nutt.) Lindl. & Endangered in FL, NJ, TN & Zettler et al. 2000 \\
\hline P. integrilabia (Correll) Luer & U.S. Federal Threatened (proposed) & Yoder et al. 2000 \\
\hline P. leucophaea (Nutt.) Lindl. & U.S. Federal Threatened & $\begin{array}{l}\text { Bowles et al. } 2002 \\
\text { Zettler } \text { et al. } 2001 \\
\text { Zettler et al. } 2005 \mathrm{~b}\end{array}$ \\
\hline Spiranthes brevilabris Lindl. & Endangered in FL & Stewart et al. 2003 \\
\hline
\end{tabular}


Hawaiian endemic - in collaboration with Steve Perlman (National Tropical Botanical Garden). Another significant, student-led project was recently initiated that aims to propagate/reintroduce four rare orchids of south Florida: Epidendrum amphistomum A. Richard, E. rigidum Jacq., Polystachya concreta (Jacquin) Garay \& Sweet and Vanilla phaeantha Rchb.f. Students working in collaboration with Scott Stewart (University of Florida) and Larry Richardson (U.S. Fish \& Wildlife Service) are attempting to cultivate these orchids with and without fungi. So far, at least two of the species have been propagated to the leaf-bearing stage in vitro.

Overall, research in the Orchid Recovery Program has led to 12 published papers in scientific (refereed) journals co-authored by 13 different undergraduate students. In addition, 20 different students have coauthored 20 published abstracts via presentations at national or international meetings. This program may, therefore, be viewed as a successful 10-year experiment to promote orchid conservation in North America. In doing so, it has instilled an appreciation for biological diversity in the next generation of caretakers. It also represents one working model of how research can be established and maintained at similar small colleges in the United States and perhaps elsewhere. It is this author's opinion that conservation must infiltrate (expand) within academia, in both vocabulary and practice. It seems unfortunate that a disproportionate number of organismal biologists, at large and small institutions alike, have little or no (direct) link to conservation. If true, such apathy or indifference towards our planet's natural resources is especially disheartening when these academicians themselves should be at the forefront of conservation. Unless this perceived attitude changes, the species extinctions projected to occur this century will almost certainly be realized.

Acknowledgments. I warmly thank my wife, Dr. Elizabeth Rellinger Zettler (Illinois College), for her critique of the manuscript. Sincere appreciation is also extended to my departmental colleagues, Dr. Elaine S.
Chapman (professor and chair), Juanita B. "Penny" Leonhard (instructor), and Andy Stice (lab manager) for their unwavering support.

\section{LiterATURE CITED}

Bowles, M.L., K.A. Jacobs, L.W. Zettler \&T. Wilson Delaney. 2002. Crossing effects on seed viability and experimental germination of the Federal threatened eastern prairie fringed orchid, Platanthera leucophaea (Nutt.) Lindl. Rhodora 104: 14-30.

Stewart, S.L. 2002. Saving a native orchid. Orchids Magazine 71: 916-919.

Stewart, S.L. \& L.W. Zettler. 2002. Symbiotic germination of three semi-aquatic rein orchids (Habenaria macroceratitis, H. quinqueseta, $H$. repens) from Florida. Aquatic Bot. 72: 25-35.

Yoder, J.A., S.L. Stewart \& L.W. Zettler. 2000. Water requirements of terrestrial andepiphytic orchid seeds and seedlings, and evidence for water uptake by means of mycotrophy. Plant Sci. 156: 145-150.

Zettler, L.W. 2006. Endemics: ghosts in the making. Native Orchid Conf. J. 3(3): 14-17.

Zettler, L.W., S. Perlman, D.J. Dennis, S.E. Hopkins \& S.B. Poulter. 2005. Symbiotic germination of the Federally endangered Hawaiian endemic, Platanthera holochila (Orchidaceae) using a mycobiont from Florida: a conservation dilemma. Selbyana $(1,2)$ : 269-276.

Zettler, L.W., K.A. Piskin, S.L. Stewart, J.J. Hartsock, M.L. Bowles \& T.J. Bell. 2005. Protocorm mycobionts of a Federally threatened orchid, Platanthera leucophaea, and a technique to promote leaf formation in seedlings. Stud. Mycol. 53: 153-161.

Zettler, L.W., S.B. Poulter, K.I. McDonald \& S.L. Stewart. 2007. Conservation-driven propagation of an epiphytic orchid (Epidendrum nocturnum) with a mycorrhizal fungus. HortSci. 42: (in press).

Zettler, L.W., S.L. Stewart, M.L. Bowles \& K.A. Jacobs. 2001. Mycorrhizal fungi and cold-assisted symbiotic germination of the Federally threatened eastern prairie fringed orchid, Platanthera leucophaea (Nutt.) Lindl. Am. Mid. Nat. 145: 168-175.

Zettler, L.W., J.A. Sunley \& T. Wilson Delaney. 2000. Symbiotic seed germination ofan orchid in decline (Platanthera integra) from the Green Swamp, North Carolina. Castanea 65: 207-212.

Lawrence W. Zettler earned a BS degree in entomology at the University of Florida (1987), and a PhD in plant physiology at Clemson University (1994). He is an associate professor at Illinois College, a research associate at The Morton Arboretum (Lisle, IL) and Marie Selby Botanical Garden (Sarasota, FL), and a member of the American Orchid Society's Research Committee. As a biological illustrator, his color artwork has been published in two recent texts (Dragonflies of North America, Scientific Publishers, 2000; The Black Flies (Simuliidae) of North America, Cornell University Press, 2004). 